\title{
Perkembangan dan Kandungan Nutrisi Larva Hermetia illucens (Linnaeus) (Diptera: Stratiomyidae) pada Bungkil Kelapa Sawit
}

\author{
RACHMAWATI ${ }^{1)}$, DAMAYANTI BUCHORI ${ }^{2}$, PURNAMA HIDAYAT ${ }^{2)}$, \\ SAURIN HEM ${ }^{3)}$, DAN MELTA R. FAHMI) \\ ${ }^{1)}$ Mahasiswa Pascasarjana Mayor Entomologi Institut Pertanian Bogor \\ ${ }^{2)}$ Departemen Proteksi Tanaman, Fakultas Pertanian, Institut Pertanian Bogor \\ ${ }^{3)}$ Institut de Recherche pour le Développement \\ ${ }^{4)}$ Balai Riset Budidaya Ikan Hias
}

(diterima Januari 2010, disetujui Maret 2010)

\begin{abstract}
Development and nutrional content of Hermetia illucens (Linnaeus) (Diptera: Stratiomyidae) larvae on oilpalm kernel. Hermetia illucens, is used as a reducing agent of palm kernel meal (PKM), as well as one of alternative protein sources for aquaculture purposes. Information about biology of $H$. illucens is absolutely required in mass production. The objectives of these researches were to study the development of H. illucens including the effect of supplementary food to the adult, and nutrient content of the immature stage. The sample of 20 larvae from each 3 replicates were measured and weighed on 0-19th day (larva) and 24th day (pupa) from egg hatching. H. illucens adults were fed by water and honey $5 \%(\mathrm{v} / \mathrm{v})$. Eggs were collected and counted. Nutrient content of immature stage: $5,10,15$, 20 days old (larvae), and 25 days old (prepupae) reared on PKM were analyzed proximately. Dry matter was determined by weight loss on drying at $105{ }^{\circ} \mathrm{C}$ during overnight. Crude protein was determined by Kjeldahl procedure $(\mathrm{N} \times 6.25)$, crude fat by soxhlet (ether extract), crude ash by determining the residue after heating at $550{ }^{\circ} \mathrm{C}$ for $4-5 \mathrm{~h}$. Data were analyzed descriptively by average from triplicate. The development of $H$. illucens was shorter than those in previous studies as the differences of abiotical factor. PKM was a suitable medium for development. It was better, however, to fed the adult with honey since it could enhance the fecundity. The young larva certainly contained the best quality of nutrition. To meet the quantity of mass production, however, the use of the elder larva (bigger) was suggested.
\end{abstract}

KEY WORDS: Hermetia illucens, development, PKM, proximate analysis

\section{PENDAHULUAN}

Hermetia illucens merupakan salah satu jenis serangga potensial untuk dimanfaatkan, antara lain sebagai: agen pengurai limbah organik (Lardé
1990, Sheppard et al. 1994, Leclercq 1997, Olivier 2001, Newton et al. 2005), pakan tambahan bagi ikan dan hewan ternak (Newton et al. 1977, Bondari \& Sheppard 1981, Bodri \& Cole 2007, St-Hilaire et al. 2007). 
Hermetia illucens dapat dijadikan sebagai salah satu kandidat sumber protein alternatif pengganti tepung ikan, yang ketersediannya mulai terbatas. Sejak tahun 1995, harga tepung ikan meningkat dari $\mathrm{A} \$ 450$ per ton hingga mencapai A $\$ 1300$ per ton pada tahun 2006. Sekarang, nilainya bertahan pada tingkat A $\$ 1200$ per ton. Harga tepung ikan yang tinggi akan mempengaruhi harga pakan serta biaya produksi. Kondisi tersebut memicu banyak peneliti di bidang terkait untuk mencari sumber protein alternatif, yang lebih murah dan tersedia dalam skala lokal, untuk menggantikan sebagian proporsi tepung ikan dalam komposisi pakan (Hardy 2006, FAO 2007). Hem et al. (2008) telah mengembangbiakkan larva $H$. illucens di Republik Guinea untuk pakan ikan nila (Oreochromis niloticus). Media pertumbuhan larva yang digunakan adalah salah satu limbah lokal dari industri minyak kelapa sawit, yaitu bungkil kelapa sawit (palm kernel meal/PKM).

Indonesia memiliki kapasitas produksi minyak sawit yang mengungguli produsen dari negara lainnya (USDA 2007, Santosa 2008). Pada tahun 2007, area perkebunan kelapa sawit mencapai luasan 6.65 juta hektar atau sepuluh kali lebih luas daripada luasan di tahun 1985. Total produksi minyak sawit pada tahun 2007 adalah 17 juta ton CPO dan 1,9 juta ton PKO (Santosa 2008). Dengan demikian, kelimpahan PKM merupakan potensi lokal untuk mengembangkan sumber protein alternatif larva $H$. illucens.

Berdasarkan hasil riset yang dilakukan di lapangan, diketahui bahwa untuk memperoleh $1 \mathrm{~kg}$ larva $H$. illucens segar dibutuhkan $3 \mathrm{~kg}$ PKM. Untuk memperoleh $1 \mathrm{~kg}$ larva $H$. illucens kering (bahan baku untuk pakan) diperlukan $3 \mathrm{~kg}$ larva $H$. illucens segar (kadar air 63,72\%). Dari laporan hasil uji coba produksi larva H. illucens di Sungai Gelam (Jambi), diketahui bahwa harga pelet berbasis larva $H$. illucens yang dihasilkan hanya Rp 3500,00 per kilogram (harga PKM Rp 200,00/kg), lebih murah daripada harga pelet komersial, yaitu $\mathrm{Rp}$ 7000,00 per kilogram.

Informasi mengenai aspek biologi H. illucens di Indonesia khususnya pada PKM belum tercatat dengan baik, padahal informasi tersebut sangat diperlukan dalam wacana rencana kerja produksi massal. Oleh karena uji coba produksi yang telah dilakukan adalah produksi yang mengandalkan populasi alami, maka pengetahuan dasar mengenai $H$. illucens sangat diperlukan guna keberlanjutan produksi dan kelestarian populasi alaminya. Pengetahuan mengenai perkembangan $H$. illucens pada PKM termasuk aspek reproduksi imago terhadap pakan tambahan berupa madu, serta kandungan nutrisi larva dan prepupa, diharapkan dapat menjadi pengetahuan dasar dalam pengembangan teknologi produksi mas- 
sal larva $H$. illucens serta pemeliharaan kelestariannya di alam.

\section{BAHAN DAN METODE}

\section{Lokasi}

Penelitian dilakukan di laboratorium dan kandang produksi $H$. illucens IRD-BRBIH (Balai Riset Budidaya Ikan Hias) Depok pada bulan April 2009 hingga Desember 2009.

PKM berasal dari PT. Perkebunan Nusantara VII, Unit Usaha Bekri, Kecamatan Bekri, Lampung Tengah. PK$\mathrm{M}$ tersebut mengandung (dari 95,44\% kadar kering) $15,76 \%$ protein, $12,74 \%$ lemak, 4,16\% abu, dan 25,10\% serat kasar. Media pertumbuhan larva dibuat dengan cara mencampur PKM dengan air (1 bobot PKM : 2 bobot air), kemudian media dibiarkan terfermentasi selama paling tidak satu minggu di dalam tong plastik.

Pada uji pengaruh pakan tambahan terhadap lama hidup imago dan produksi telur, digunakan madu 5\% (v/v) dan air sebagai kontrolnya. Madu (NADHIF Natural Honey, Nadhif Lautan Alami, Mojokerto) diencerkan dengan air.

Telur H. illucens diperoleh dari populasi alami di area sekitar laboratorium. Bak-bak plastik diisi $3 \mathrm{~kg}$ media, kemudian ditutupi dengan daun pisang kering. Imago betina meletakkan telur pada daun-daun tersebut. Daun-daun tersebut diperiksa setiap pagi untuk kepastian adanya telur-telur yang baru diletakkan. Setiap kelompok telur baru (mungkin satu clutch, yang berasal dari satu induk) pada hari tersebut dicatat dan dikoleksi dengan hati-hati.

\section{Siklus Hidup dan Pengaruh Pakan Tambahan terhadap Lama Hidup Imago dan Produksi Telur}

Tiga kelompok telur baru dikoleksi di wadah yang terbuat dari alumunium foil dan diinkubasi langsung di dalam kotak plastik (p 27,3 cm; $121 \mathrm{~cm}$; 20 $\mathrm{cm})$ berisi $3 \mathrm{~kg}$ media PKM fermentasi. Kotak disimpan pada suhu dan kelembaban lingkungan. Sebanyak 20 ekor sampel larva diambil secara acak setiap hari sampai tahapan prepupa untuk ditimbang dan diukur. Sampel kemudian dikembalikan lagi. Prepupa dikoleksi dan dikumpulkan pada kotak berisi daun pisang kering sebagai shelter selama pupasi. Ketika prepupa mencapai tahapan pupa, masingmasing 20 sampel pupa ditimbang. Kemudian sebanyak 600 pupa dikoleksi dan dibagi menjadi dua kelompok. Masing-masing dimasukkan ke dalam kandang (p 2,00 m; 1 1,20 m; t 1,55 m; $\mathrm{t}$ dari tanah $0,75 \mathrm{~m})$. Ketika imago muncul, satu kandang diberi perlakuan pakan madu, dan yang lainnya diberi air. Pakan tersebut disemprotkan pada sisi-sisi kandang di pagi dan sore hari. Imago yang muncul dihitung tiap hari dari jumlah puparia. Ke dalam kandang tersebut diletakkan sebanyak 3 basket (p $10 \mathrm{~cm} ; 17,5 \mathrm{~cm} ; \mathrm{t} 4 \mathrm{~cm}$ ) berisi media PKM dan daun kering sebagai substrat untuk oviposisi. Telur 
yang terlihat dikoleksi dan disimpan di dalam etanol $70 \%$ untuk kemudian dihitung dengan bantuan Program Image J. Imago yang mati dikoleksi, diperiksa jenis kelaminnya, dan dicatat.

\section{Hubungan Keperidian dengan Ukuran Tubuh Imago Betina}

Penelitian ini diawali dengan menangkap pasangan imago yang sedang kopulasi. Tiap pasangan dipindahkan dengan hati-hati ke dalam wadah plastik transparan (d $20 \mathrm{~cm}$; $20 \mathrm{~cm})$. Ke dalam wadah tersebut diletakkan 1 basket seperti disebut sebelumnya. Wadah ditutup dengan kain jaring nilon, kemudian disimpan di dalam kandang. Keberadaan telur diperiksa setiap hari. Ketika terlihat, telur dikoleksi untuk dihitung, dan imago betina diambil untuk diukur panjang tubuhnya.

\section{Analisis Proksimat Kandungan Nutrisi Larva-Prepupa}

Beberapa kelompok telur baru dikoleksi di wadah yang terbuat dari kertas aluminium, ditimbang, dan diinkubasi langsung di dalam kotak plastik berisi media PKM fermentasi sebanyak 2000 kali bobot telur (berdasarkan penelitian pendahuluan). Hari penetasan telur dicatat sebagai hari ke0 . Kemudian, 20 gram sampel $H$. illucens pradewasa berumur 5, 10, 15, 20 hari (larva) dan 25 hari (prepupa) diambil, digiling, kemudian disimpan di dalam lemari pembeku untuk sementara. Analisis proksimat meliputi kadar bahan kering, protein kasar, lemak kasar, dan abu kasar. Kadar bahan kering ditentukan dengan menghitung kehilangan bobot selama proses pengeringan pada suhu $105{ }^{\circ} \mathrm{C}$ yang berlangsung selama semalam. Kadar protein kasar ditentukan dengan prosedur Kjeldahl ( $\mathrm{N}$ x 6.25), kadar lemak kasar dengan Soxhlet (ekstrak eter), dan kadar abu kasar dihitung dari residu setelah pemanasan pada suhu $550{ }^{\circ} \mathrm{C}$ selama $4-5$ jam (Hart \& Fisher 1971). Data dianalisis secara deskriptif dengan menghitung rata-rata dari tiga ulangan.

\section{HASIL DAN PEMBAHASAN}

\section{Siklus Hidup dan Pengaruh Pakan terhadap Lama Hidup Imago dan Produksi Telur}

Telur H. illucens melewati masa inkubasi selama 72 jam atau 3 hari (Gambar 1). Perubahan-perubahan yang dapat diamati di bawah mikroskop stereo antara lain: (a) telur yang baru diletakkan tampak dipenuhi dengan massa kuning telur; (b) dalam 24 jam telah terjadi embriogenesis, yang dapat terlihat antara lain segmentasi bakal tubuh larva; (c) dalam 48 jam bentuk tubuh larva mulai terlihat jelas, terdapat bintik mata merah dan bagian mulut yang mulai berpigmen; (d) dalam 72 jam tampak bagianbagian yang lebih jelas seperti saluran spirakel yang memanjang dari lateral spirakel menuju posterior spirakel, 


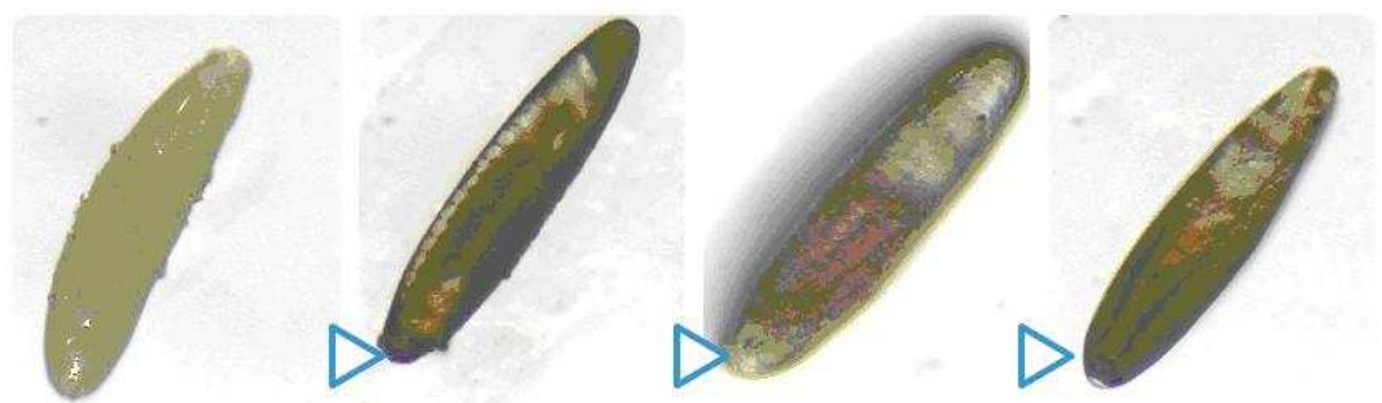

Gambar 1. Tahapan perkembangan telur H. illucens yang diamati di bawah stereomikroskop. (a) 1 jam; (b) 24 jam; (c) 48 jam; (d) 72 jam

Tabel 1. Pertumbuhan H. illucens pradewasa pada media PKM

\begin{tabular}{clll}
\hline \hline Umur (hari) & Panjang $(\mathrm{mm})$ & Lebar $(\mathrm{mm})$ & Bobot $(\mathrm{g})$ \\
\hline 4 & $6,9 \pm 0,6^{\mathrm{a}}$ & $2,0 \pm 0,2^{\mathrm{a}}$ & $0,01 \pm 0,00^{\mathrm{a}}$ \\
6 & $12,3 \pm 1,6^{\mathrm{b}}$ & $3,8 \pm 0,4^{\mathrm{b}}$ & $0,06 \pm 0,02^{\mathrm{b}}$ \\
8 & $15,1 \pm 0,7^{\mathrm{c}}$ & $4,8 \pm 0,2^{\mathrm{c}}$ & $0,10 \pm 0,01^{\mathrm{c}}$ \\
10 & $16,4 \pm 0,5^{\text {cd }}$ & $5,0 \pm 0,1^{\mathrm{cd}}$ & $0,12 \pm 0,01^{\mathrm{cd}}$ \\
12 & $17,2 \pm 0,1^{\text {de }}$ & $5,3 \pm 0,2^{\text {cde }}$ & $0,14 \pm 0,01^{\mathrm{de}}$ \\
14 & $18,2 \pm 0,5^{\text {def }}$ & $5,5 \pm 0,1^{\mathrm{de}}$ & $0,16 \pm 0,01^{\text {ef }}$ \\
16 & $19,1 \pm 0,5^{\text {ef }}$ & $5,7 \pm 0,3^{\mathrm{e}}$ & $0,17 \pm 0,01^{\mathrm{ef}}$ \\
18 & $19,9 \pm 0,3^{\mathrm{f}}$ & $5,7 \pm 0,2^{\mathrm{e}}$ & $0,18 \pm 0,02^{\mathrm{f}}$ \\
24 & $19,9 \pm 0,6^{\mathrm{f}}$ & $5,5 \pm 0,3^{\mathrm{de}}$ & $0,16 \pm 0,01^{\text {ef }}$ \\
\hline
\end{tabular}

Nilai rata-rata \pm SD, Notasi sama pada kolom yang sama menunjukkan tidak berbeda nyata pada taraf kepercayaan $95 \%$ dengan uji Tukey.

serta bintik mata dan bagian mulut yang tampak semakin jelas, pergerakan tubuh embrio juga terlihat. Telur menetas, larva muncul dan langsung memasuki tahap makan. Laju pertumbuhan relatif larva sangat pesat hingga hari ke-8. Bobot tubuh juga terus bertambah sampai ketika hendak memasuki tahapan prepupa. Karena tahapan prepupa adalah tahapan ketika tidak lagi dilakukan aktivitas makan, maka ada kecenderungan ketika hendak memulai inisiasi pupa, bobot tubuh prepupa menjadi sedikit berkurang (Tabel 1).
Tahapan larva yang masih berkulit putih berlangsung kurang lebih 12 hari. Selanjutnya larva mulai berubah warna menjadi coklat dan semakin gelap seminggu kemudian. Prepupa sejak hari ke-19. Pupa $100 \%$ dicapai pada hari ke-24.Tahapan pupa berlangsung berikutnya selama 8 hari kemudian, Imago mulai muncul pada hari ke-32. Imago yang muncul dari pupa, yang kemudian diberi perlakuan pakan tambahan air dan madu, menunjukkan sedikit perbedaan pada lama hidup dan 

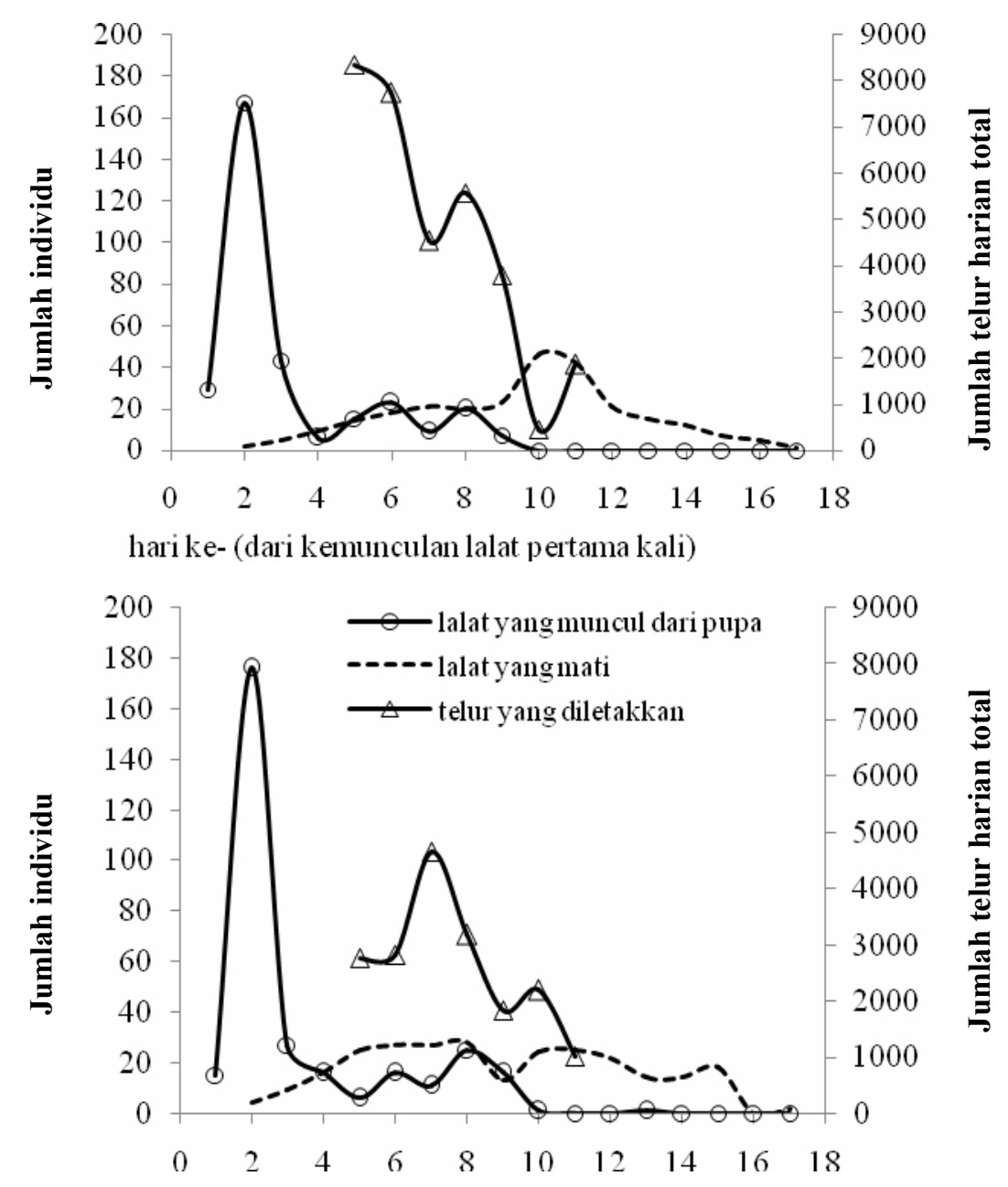

Gambar 2. Ciri imago $H$. illucens yang diberi pakan tambahan air (atas) dan madu (bawah)

jumlah telur. Karena berasal dari populasi yang sama maka puncak kemunculan imago pada kedua perlakuan adalah sama, Pada populasi imago yang diberi madu tampak adanya puncak dari kematian sedangkan pada populasi yang diberi air tidak demikian. Sementara itu, pada grafik yang sama tampak bahwa puncak kemunculan dengan puncak kematian imago yang diberi pakan madu berjarak 8-9 hari. Jumlah telur pada per- lakuan pakan madu juga tampak lebih banyak daripada perlakuan pemberian air. Puncak oviposisi pada populasi yang diberi pakan madu adalah pada hari ke-5 sedangkan pada perlakuan pemberian air adalah pada hari ke-7. Bila mengacu pada puncak kemunculan imago dari pupa, maka masa praoviposisi adalah sekitar 3 hari pada populasi yang diberi pakan madu, dan 5 hari pada populasi yang diberi air (Gambar 2). 


\section{Hubungan Keperidian dengan Ukuran Tubuh Imago Betina}

Morfometri (panjang tubuh, panjang antena, serta panjang dan lebar sayap) H. illucens betina relatif lebih besar daripada jantan (Tabel 2). Keperidian imago betina berkisar antara 185 dan 1235 telur. Berdasarkan garis regresi linear, jumlah telur berbanding lurus dengan ukuran tubuh (Gambar 3). Betina hanya satu kali meletakkan telur, setelah itu tidak lagi ditemukan ovarium yang berkembang.

\section{Analisis Proksimat Kandungan Nutrisi Larva-Prepupa}

Kadar bahan kering larva meningkat menurut umur. Kadar bahan kering berkisar antara 26,61\% (larva umur 5 hari) dan 39,97\% (prepupa). Peningkatan kadar lemak tampak pesat sejak hari ke-10. Kadar lemak kasar berkisar antara 13,37\% (larva umur 5 hari) dan 27,50\% (prepupa). Kadar protein kasar larva menurun drastis setelah hari ke-5. Pada hari ke-5, kadar protein bernilai $61,42 \%$. Sejak hari ke10 hingga hari ke-25, kadarnya

Tabel 2. Morfometri H. illucens

\begin{tabular}{ccccc}
\hline \multirow{2}{*}{ Jenis kelamin } & \multicolumn{3}{c}{ Morfometri rata-rata $(\mathrm{mm}) \pm \mathrm{SD}$} \\
\cline { 2 - 5 } & \multirow{2}{*}{ panjang tubuh } & panjang antena & panjang & lebar \\
\cline { 2 - 5 } & $12,7 \pm 1,1$ & $3,2 \pm 0,4$ & $9,4 \pm 0,7$ & $3,3 \pm 0,2$ \\
jantan & $13,5 \pm 1,4$ & $3,8 \pm 0,4$ & $10,6 \pm 0,9$ & $3,9 \pm 0,4$ \\
betina & & &
\end{tabular}

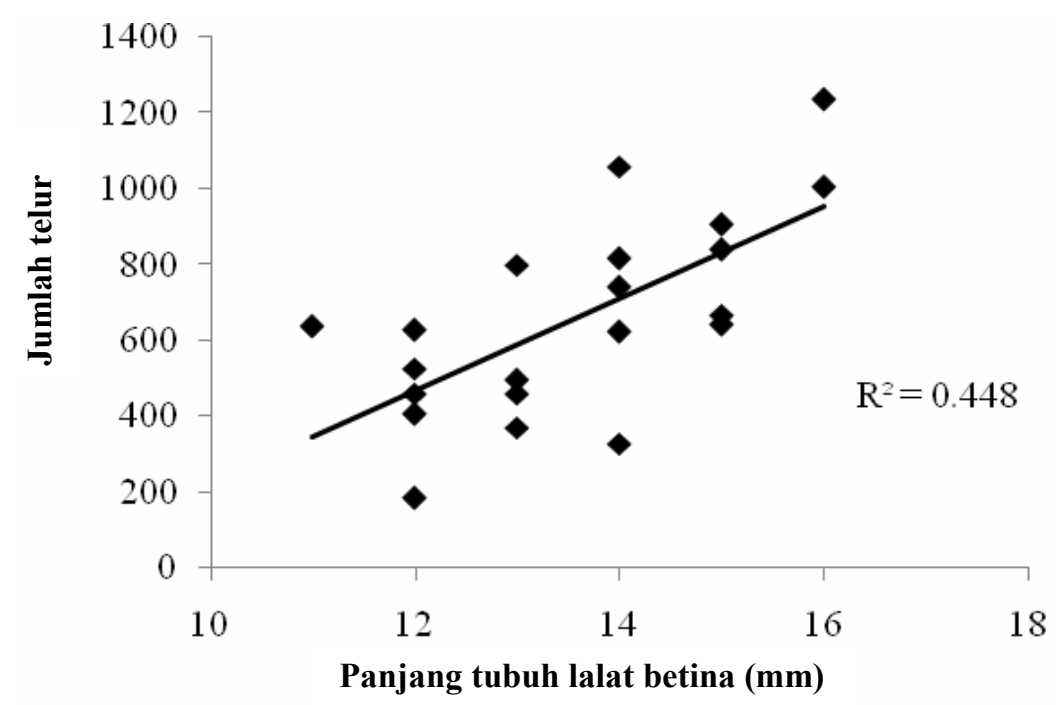

Gambar 3. Hubungan panjang tubuh $H$. illucens betina dengan jumlah telur 
berkisar antara 42,07\% dan 45,85\%. Kadar abu kasar pada setiap umur tampak sedikit fluktuatif namun nilainya masih berkisar antara 7,65\% dan 11,36\% (Tabel 3). Setelah diletakkan pada substrat yang tepat, telur akan segera memasuki masa inkubasi. Pada penelitian ini, masa inkubasi telur $H$. illucens berlangsung lebih singkat daripada masa inkubasi $H$. illucens di beragam tempat. Pada suhu $24{ }^{\circ} \mathrm{C}$, telur H. illucens menetas dalam 102 sampai 105 jam (4,3 hari) (Booth \& Sheppard 1984). Di Argentina, telur menetas 4 sampai 6 hari. Di Selandia Baru telur menetas 5 hari di bulan Februari dan 7 sampai 14 hari di bulan April (Sheppard et al. 2002). Oleh karena pada penelitian ini, waktu inkubasi total telur berlangsung kurang lebih satu hari lebih singkat, maka perkembangan embrionik yang teramati pada penelitian ini juga berlangsung lebih cepat daripada yang dipaparkan oleh Booth and Sheppard (1984).

Perbedaan waktu perkembangan tersebut diduga disebabkan oleh faktor suhu dan kelembaban udara, karena suhu lingkungan dan kelembaban berkorelasi negatif dengan waktu inkubasi telur atau perkembangan embrio (Chapman 1998). Hubungan antara suhu lingkungan dan waktu perkembangan dapat digunakan untuk menghitung (suhu dikalikan waktu) pemasukan panas total (total heat input) atau derajat hari (degree days). Bila suhu lingkungan dikompensasi dengan lamanya waktu inkubasi, maka sesungguhnya derajat hari untuk perkembangan suatu spesies adalah sama untuk setiap suhu lingkungan di atas suhu minimum untuk perkembangan embrio secara penuh (full development) (Zalom et al. 1983, Chapman 1998). Jadi, meskipun suhu minimum untuk perkembangan embrio secara

Tabel 3. Kandungan nutrisi $H$. illucens pradewasa pada media PKM

\begin{tabular}{ccccr}
\hline \hline \multirow{2}{*}{ umur (hari) } & \multicolumn{4}{c}{ Kadar (\%) } \\
\cline { 2 - 5 } & Bahan kering & Protein kasar & Lemak kasar & Abu kasar \\
\hline 5 & 26,61 & 61,42 & 13,37 & 11,03 \\
10 & 37,66 & 44,44 & 14,60 & 8,62 \\
15 & 37,94 & 44,01 & 19,61 & 7,65 \\
20 & 39,20 & 42,07 & 23,94 & 11,36 \\
25 & 39,97 & 45,87 & 27,50 & 9,91 \\
\hline Rata-rata & 36,28 & 47,56 & 19,80 & 9,71 \\
SD & 5,48 & 7,86 & 6,02 & 1,58 \\
\hline
\end{tabular}


penuh dan derajat hari penetasan telur $H$. illucens belum diketahui, namun dapat diduga bahwa nilainya sama antara penelitian ini dengan penelitianpenelitian sebelumnya.

Tomberlin et al. (2009) telah membuktikan bahwa suhu dapat mempengaruhi waktu perkembangan larvapupa $H$. Illucens. Larva dan pupa $H$. illucens yang dipelihara pada suhu 27 ${ }^{\circ} \mathrm{C}$, berkembang lebih lambat $(\approx 4$ hari $)$ daripada yang dipelihara pada suhu 30 ${ }^{\circ} \mathrm{C}$, sementara pada suhu $36{ }^{\circ} \mathrm{C}$, hampir tidak ada pupa yang sintas. Hal tersebut menunjukkan bahwa pemasukan panas total (total heat input) yang diterima oleh larva yang dipelihara pada suhu $30{ }^{\circ} \mathrm{C}$ lebih cepat terpenuhi, guna melengkapi syarat perkembangan menuju tahap pupa, daripada larva yang dipelihara pada suhu $27{ }^{\circ} \mathrm{C}$.

Selain suhu, kualitas media pertumbuhan juga dapat memengaruhi waktu perkembangan. Perkembangan larva $H$. illucens pada penelitian ini (19 hari) berlangsung sedikit lebih singkat daripada yang dikaji oleh Tomberlin et al. (2002). Perbedaan perkembangan $H$. illucens antar media tersebut, termasuk PKM, diduga karena kandungan nuntrisi media pertumbuhan larva tersebut tidak jauh berbeda (Tabel 4). Kuantitas media pertumbuhan juga tidak kalah penting. Pada tingkat ransum yang rendah (pakan berupa kotoran sapi), larva berkembang lebih lambat daripada tingkat ransum yang tinggi (Myers et al. 2008).

Lama hidup $H$. illucens dewasa berkisar antara 1 dan 2 minggu bergantung pada pakan larva dan juga pakan tambahan pada tahapan dewasa tersebut. Imago yang diberi air dapat hidup lebih lama daripada yang tidak diberi air sama sekali (Tomberlin et al. 2002, Myers et al. 2008). Pada penelitian ini, imago yang diberi pakan madu hidup kurang lebih sama dengan yang diberi air saja. Namun, betina yang diberi pakan madu meletakkan telur lebih banyak daripada yang diletakkan betina yang diberi air saja. Seperti serangga dewasa pada umumnya dan parasitoid pada khususnya, madu atau sumber gula lainnya (embun madu, nektar, nektar selain dari bunga) merupakan salah satu sumber untuk memenuhi kebutuhan nutrisi jangka pendek untuk mencari inang yang sesuai (Lewis et al. 1998). Pada Cotesia marginiventris (Hymenoptera: Braconidae), madu mampu meningkatkan produksi telurnya (Riddick 2007). Hermetia illucens bukan termasuk ke dalam serangga proovigenik, karena betina dewasa yang muncul dari pupa tidak membawa sejumlah telur matang (Tomberlin et al. 2002). Penelitian ini juga menunjukkan bahwa $H$. illucens hanya meletakkan telur satu kali dalam hidupnya, karena ovarium tidak lagi berkembang pasca oviposisi. Dengan 
Tabel 4. Kandungan nutrisi pakan (\%) larva H. illucens

\begin{tabular}{lccccc}
\hline \hline Jenis nutrien & $\begin{array}{c}\text { Terigu } \\
\text { fermentasi }\end{array}$ & PKM $^{1}$ & Gainesville $^{2}$ & CSMA $^{2}$ & Pakan ayam $^{2}$ \\
\hline Protein & 14,62 & 15,76 & 15,3 & 19,0 & 15,0 \\
Lemak & 0,03 & 12,74 & 3,8 & 3,0 & 3,0 \\
Serat & 2,11 & $25,10^{3}$ & 12,6 & 20,0 & 5,0 \\
Abu & 0,83 & 4,16 & 6,3 & 8,0 & 13,7 \\
\hline
\end{tabular}

${ }^{1)}$ PKM berasal dari PT. Perkebunan Nusantara VII, Lampung; ${ }^{2)}$ Media pertumbuhan larva $H$. illucens yang digunakan oleh Tomberlin et al. (2002); Gainesville: pakan lalat rumah; CSMA: pakan buatan untuk larva lalat rumah; ${ }^{3)}$ Analisis dengan cellite

demikian, $H$. illucens diduga termasuk serangga sinovigenik. Hal tersebut diduga menjadi penyebab singkatnya lama hidup $H$. illucens dewasa.

Sebagai serangga sinovigenik, imago $H$. illucens menggunakan cadangan energi (dalam bentuk badan lemak) yang ditimbunnya selama tahapan pradewasa (larva). Kelak cadangan energi tersebut digunakan imago untuk alokasi reproduksi dan sintasan, Dengan demikian, porsi alokasi reproduksi bisa saja berkurang guna memenuhi kebutuhan sintasan. Bila pada tahapan tersebut imago betina memperoleh makanan tambahan, maka diharapkan porsi untuk alokasi reproduksi tidak berkurang, bila mungkin bertambah. Pakan tambahan berupa madu 5\% diduga tidak terlalu mempengaruhi lama hidup. Akan tetapi, pakan tambahan diduga dapat mempengaruhi keperidiaannya.

Dalam konteks produksi larva $H$. illucens, madu menjadi salah satu solusi untuk meningkatkan kuantitas produksi. Madu yang diberikan kepada imago dapat meningkatkan jumlah telur. Di tambah lagi, waktu perkembangan pradewasa yang relatif lebih singkat akan meningkatkan jumlah generasi per tahun yang berarti bahwa kuantitas produksi larva menjadi meningkat.

\section{Kandungan Nutrisi $\boldsymbol{H}$. illucens Pradewasa}

Selama perkembangan biomassa dan volume akan meningkat, sehingga mengubah komposisi kandungan nutrisi. Perubahan kuantitas cadangan lemak yang diperuntukkan bagi proses metamorfosis tampak pada suatu spesies jangkrik, Gryllus bimaculatus (Anand \& Lorenz 2008). Pengakumulasian lemak dalam proporsi yang banyak atau semakin meningkat, merupakan salah satu strategi serangga dalam menghadapi ketidakpastian kualitas pakan yang akan datang (Hahn 2005). Sementara itu, cadangan lemak yang diperuntukkan bagi reproduksi tampak pada sejumlah badan lemak $H$. illucens betina dewasa yang digunakan untuk perkembangan ovariol (Tomberlin et al. 2002). 
Individu yang lebih besar, atau dalam studi ini adalah yang lebih tua, mengandung lebih banyak lemak dan protein. Larva muda mengalami pertumbuhan somatik yang pesat (Tabel 1). Namun, ketika pertumbuhan sel somatik telah konstan, maka perubahan hanya terjadi pada kadar lemak (Hahn 2005). Hal tersebut dapat dijadikan alasan mengapa kadar protein kasar dan kadar bahan kering larva $H$. illucens cenderung sedikit mengalami peningkatan sejak hari ke-10. Protein struktural, seperti dinding sel, juga turut berkontribusi atas tingginya kadar protein pada larva muda.

$\mathrm{Abu}$ adalah konstituen anorganik dan berasal dari mineral. Abu merupakan bahan yang tidak tercernakan sehingga tidak menghasilkan energi. Oleh karena itu, sebaiknya kandungan abu dalam pakan bernilai rendah. Kadar abu kasar pada larva H. illucens kurang lebih sama dengan kadar abu serangga-serangga yang dijadikan pakan bagi masyarakat Thailand. Menurut Raksakantong et al. (2010), profil nutrisi yang dimiliki seranggaserangga tersebut tergolong baik.
Bila dibandingkan PKM dan tepung ikan, profil nutrisi $H$. illucens berada di antara keduanya (Tabel 5). Kandungan protein larva jauh lebih tinggi daripada PKM, dan sedikit di bawah tepung ikan lokal. Hal tersebut menunjukkan bahwa proses biokonversi ini (protein PKM menjadi protein larva) dapat meningkatkan nilai kegunaan PKM untuk dapat digunakan dalam bidang akuakultur dan peternakan, yaitu menggantikan proporsi tepung ikan dalam komposisi pakan.

Kadar protein yang terbaik dikandung oleh larva muda. Namun demikian dalam konteks produksi massal, kuantitas produksi menjadi pertimbangan lainnya dalam pemanfaatan larva muda tersebut. Larva muda tersebut (yaitu yang berukuran kecil) dapat diberikan langsung sebagai pakan hidup (life feed) kepada ikan dengan bukaan mulut yang sesuai dengan ukuran larva. Untuk peruntukan lain, seperti pemanfaatan larva $H$. illucens sebagai salah satu bahan campuran pakan atau bahan baku pelet

Tabel 5. Kandungan nutrisi bahan pakan yang biasa digunakan di bidang peternakan dan akuakultur

\begin{tabular}{|c|c|c|c|}
\hline \multirow{2}{*}{ Jenis bahan } & \multicolumn{3}{|c|}{ Kadar (\%) } \\
\hline & Protein kasar & Lemak kasar & Abu kasar \\
\hline $\mathrm{PKM}^{1}$ & 15,91 & 7,83 & 4,55 \\
\hline Larva $H . ~ i l l u c e n s^{2}$ & 47,56 & 19,80 & 9,71 \\
\hline Tepung ikan ${ }^{3}$ & 54,00 & 8,72 & 25,72 \\
\hline
\end{tabular}


larva murni, maka sebaiknya digunakan larva lebih besar guna memenuhi kuantitas produksi.

\section{KESIMPULAN}

Waktu perkembangan $H$. illucens berlangsung lebih cepat daripada yang tertera pada penelitian sebelumnya. Hal tersebut disebabkan faktor lingkungan abiotik (suhu). PKM merupakan media yang sesuai bagi larva $H$. illucens untuk dapat berkembang hingga imago. Namun demikian imago $H$. illucens memerlukan pakan tambahan untuk meningkatkan jumlah telurnya. Madu merupakan salah satu pakan tambahan yang lebih baik daripada air saja. Kadar protein kasar yang terbaik dikandung oleh larva muda, sementara kadar lemak kasar tertinggi dikandung prepupa. Untuk memenuhi kapasitas produksi, disarankan untuk menggunakan larva yang berukuran lebih besar.

\section{UCAPAN TERIMAKASIH}

Terimakasih kepada IRD-BRBIH atas pendanaan dan izin lokasi penelitian ini yang merupakan bagian dari projek 'Biokonversi PKM dengan larva $H$. illucens untuk akuakultur.

\section{DAFTAR PUSTAKA}

Anand AN, Lorenz MW. 2008. Agedependent changes of fat body stores and the regulation of fat body lipid synthesis and mobilesation by adipokinetic hormone in the last larval instar of the cricket
Gryllus bimaculatus. Journal of Insect Physiology 54: 1404-1412.

Bodri MS, Cole ER. 2007. Black soldier fly (Hermetia illucens Linnaeus) as feed for the American Alligator (Alligator mississippiensis Daudin). Georgia J Science 65(2): 82-88.

Bondari K, Sheppard DC. 1981. Soldier fly larvae as feed in commercial fish production. Aquaculture 24: 103-109.

Booth DC, Sheppard C. 1984. Oviposition of the black soldier fly, Hermetia illucens (Diptera: Stratiomyidae): eggs, masses, timing, and site characteristics Environ Entomol 13(2): 421-423.

Chapman RF. 1998. The Insects: Structure and Function. Cambridge: Cambridge University Press.

[FAO] Food and Agriculture Organization. 2007. Food outlookNovember 2007 www.fao.org. [diakses 3 Desember 2008].

Hahn DA. 2005. Larval nutrition affects lipid storage and growth, but not protein or carbohydrate storage in newly eclosed adults of the grasshopper Schistocerca Amer. J Insect Physiol 51: 12101219.

Hardy RW. 2006. Worldwide fish meal production outlook and the use of alternative protein meals for aquaculture, : Suaréz LEC, Marie DR, Salazar MT, López MGN, Cavazos DAV, Cruz ACP, Ortega AG, (eds) Avances en Nutrición Acuícola VIII, VIII Simposium Internacional de Nutrición Acuícola México: 15- 
17 Noviembre, Universidad Autónama de Nuovo León.

Hart FL, Fisher HJ. 1971. Modern Food Analyses. New York: Springer-Verlag.

Hem S, Toure S, Sagbla C, Legendre M. 2008. Bioconversion of palm kernel meal for aquaculture: Experiences from the forest region (Republic of Guinea). African J Biotechnol 7(8): 11921198.

Lardé G. 1990. Recycling of coffee pulp by Hermetia illucens (Diptera: Stratiomyidae) larva. Biol Wastes 33: 307-310.

Leclercq M. 1997. A propose de Hermetia illucens (Linnaeus, 1758) ("soldier fly") (Diptera Stratiomyidae: Hermetiinae). Bulletin et Annales de la Société royale belge d'Entomologie 133: 275-282.

Lewis WJ, Stapel JO, Cortesero AM, Takasu K. 1998. Understanding how parasitoids balance food and host needs: importance to biological control. Biol Control 11: 175-183.

Myers HM, Tomberlin JK, Lambert BD, Kattes D. 2008. Development of black soldier fly (Diptera: Stratiomyidae) larvae fed dairy manure. Environ Entomol 37(1): $1-15$.

Newton GL, Booram CV, Barker RW, Hale OM. 1977. Dried Hermetia illucens larvae meal as a supplement for swine. J Animal Science 44(3): 395-400.

Newton L, Sheppard C, Watson DW, Burtle G, Dove R. 2005. Using the black soldier fly, Hermetia illucens, as a value-added tool for the management of swine manure, Directo. of the Animal and Poultry Waste Management Center North Carolina State University, Raleigh, NC, Report for Mike Williams. www.cals. Ncsu. edu [diakses 8 Oktober 2006].

Olivier P. 2001. Larval bioconversion, Electronic Forum on Livestock Environment and Development (LEAD) Initiative. http://lead.virtualcentre.org [diakses 8 Oktober 2006]

Raksakantong P, Meeso N, Kubola J, Siriamornpun S. 2010. Fatty acids and proximate composition of eight Thai edible terricolous insects. Food Research International 43: 350-355.

Riddick EW. 2007. Influence of honey and maternal age on egg load of lab-cultured Cotesia marginiventris. BioControl 52: 613-618

Santosa SJ. 2008. Palm oil boom in Indonesia: from plantation to downstream products and biodiesel. Clean 36(5-6): 453465.

Sheppard DC, Newton GL, Thompson SA, Savage S. 1994. A value added manure management system using the black soldier fly. Bioresource Technol 50: 275279.

Sheppard DC, Tomberlin JK, Joyce JA, Kiser BC, Sumner AM. 2002. Rearing methods for the black soldier fly (Diptera: Stratiomyidae), J Medic Entomol 39(4): 695-698.

St-Hilaire S, Sheppard C, Tomberlin JK, Irving S, Newton L, McGuire MA, Mosley EE, Hardy RW, 
Sealey W. 2007. Fly prepupae as a feedstuff for Rainbow Trout. Oncorhynchus mykiss $J$ World Aquaculture Soc 38(1): 59-67.

Tomberlin JK, Sheppard DC, Joyce JA. 2002. Selected lifehistory traits of black soldier flies (Diptera: Stratiomyidae) reared on three artificial diets. Annals Entomol Soc Amer 95(3): 379386.

Tomberlin JK, Adler PH, Myers HM. 2009. Development of the black soldier fly (Diptera: Stratiomyidae) in relation to tempera- ture Environmental Entomology 38(3): 930-934.

[USDA] United States Department of Agriculture. 2007. Indonesia: Palm oil production prospects continue to grow Commodity Intelligence Report. ww,pecad, fas,usda,gov [diakses 5 Desember 2008].

Zalom FG, Goodell PB, Wilson LT, Barnett WW, Bentley WJ. 1983. Degreedays: The Calculation and Use of Heat Units in Pest Management. Berkeley: Cooperative Extension University of California. 